Ethiopian Journal of Environmental Studies \& Management 8(6): 675 - 691, 2015.

ISSN:1998-0507

doi: http://dx.doi.org/10.4314/ejesm.v8i6.7

Submitted: April 19, 2015

Accepted: August 21, 2015

\title{
GEOGRAPHICAL INFORMATION SYSTEM (GIS)-BASED ANALYSIS OF ROAD TRAFFIC ACCIDENTS IN NIGERIA (1960-2012)
}

\author{
ADEBAYO, H.O. \\ Department of Geography and Regional Planning, Olabisi Onabanjo University, Ago-Iwoye, \\ Ogun State, Nigeria \\ Email: adebayooluwasegunhezekiah@gmail.com
}

\begin{abstract}
In recent years there has been serious concern on the increasing rate of road traffic accidents in Nigeria. Geographic Information System (GIS), a high performance computer based tool is useful in road traffic management and vehicular movement study. In this work, the GIS software was used to analyze and depicts the trend and characteristics of road traffic accidents in Nigeria. The data used in this study were obtained from Federal Road Safety Commission Dashboard (FRSC Planning Advisory Unit Analysis) for the year 2012 and 2013 and Nigerian Tribune Publication of Tuesday $3^{\text {rd }}$ April , 2012. The data obtained was entered and use to developed road traffic accidents information system (RTAIS). Analysis and capability of the developed system was illustrated and shown graphically. A total of 1,060,507 cases of road traffic crashes occurred between the year 1960 and 2012 of which 170,844 were fatal, 456,055 were serious and 428.790 were minor, claiming 322,427 lives. This study further revealed that Federal Capital Territory (FCT) Abuja ranked first with $6.71 \%$ based on road traffic crash fatalities per 100,000 human populations on state by state with Kebbi state being the least (0.25\%). The GIS -based analysis shows that category of vehicles involved in road traffic crashes in year 2012 on state basis varies with cars having the highest cases(4,632) followed by buses (2,239), motorcycles (1,807),truck(1,037) and tankers/trailers having the least(641). It is recommended that the Nigerian Police Force (NPF), Federal Road Safety Commission (FRSC), Vehicle Inspection Office (VIO) and other agencies linked with road traffic management and safety will find this study useful in identifying remedial measures for the improvement of safety on Nigerian roads.
\end{abstract}

Key Words: Road Traffic, Accident, GIS, Vehicles Analysis, Nigeria

\section{Introduction}

Transportation being an essential component of a sustainable livelihood provides access to basic facilities, goods and services. Hence, it enhances a good quality of life (Oyesiku, 2002). Transport is a requirement for every nation, regardless of its industrial capacity, population size or technological development. The transport sector of any country provides the means of interaction and integration of the various regions and sector of the country's economy. Thus, there is hardly any aspect of a nations development in which transport is not an essential ingredient, since there is always the need to collect, assemble, transfer and distribute people, goods and services. As an important component of national economics, road transport constitutes great danger in form of road traffic accidents worldwide. The occurrence of motor accidents on highways 
is not a strange phenomenon. Such incidence is as old as the use of automobile itself. However, the phenomenal increase in the rate at which road traffic accidents now occur is disturbing. Road traffic accidents all over the world and Nigeria in particular show a horrific and terrible picture of increasing injuries and deaths including substantial wastages of scarce resources (Jegede, 1988). Amos (2005) stated that road traffic accident maintained a steady increase from 2,579 in 1985 to 8,686 in 1990. The report further summarized that increase in rate of road accident was attributed to mass importation of fairly used vehicles into the country and also to poor physical condition of vehicles. Augustus (2012) further revealed that private cars, buses and taxis were more prone to accidents and more than $90 \%$ of road traffic accidents could be attributed to recklessness driving, ignorance of highway codes, over speeding etc.

Based on the aforementioned, it is obvious that the rate of road traffic occurrence is a complex phenomenon not only in terms of its diverse causes but also on the nature of its occurrence and effects on lives and properties. As a result of wide variety of road safety activities and measures, level of occurrence of road traffic accidents in most industrialized countries is falling. But in developing countries and Nigeria in particular, the situation is worsening with road accident deaths increasing. The socio-economic cost of increasing rate of accidents is becoming too much to bear both for citizenry and the government. Road traffic accident have far reaching social economic and environmental implication, it has been revealed that Nigeria is losing huge revenue, manpower resources and unfulfilled life through accident occurrence on Nigerian roads. Due to this reason, research into causes and control of road traffic accident would be a matter of continuous interest until the 'menace' could be kept under control. Hence there is an urgent need to analyze the trend and characteristics of road accidents so as to minimize it. These accident database are usually in the form of excel format that allow the use of statistical methods. Geographical Information System (GIS) has been identified as an excellent system for storing and managing these types of data and also as a potential tool for improving accident analysis process (Savena, 2011). One of the reasons is that it provides an efficient system of linking a large number of databases and also provides a spatial referencing system for reporting output at different levels of aggregation.

The aim of this paper is to develop road traffic accident information system in Nigeria, by centralizing the road traffic accident data and other related data on a GIS platform. The objectives of this study amongst others are:

1. The trend of road traffic accident rate in Nigeria from 1960-2012

2. State by state (including FCT, Abuja) road traffic crash fatalities per 100,000 human population using GIS techniques

3. Category of vehicles involved in road traffic crashes in 2012 on state basis.

4. The levels of cases and degrees of casualties involved in 2012 on state basis.

\section{Study Area}

Nigeria is made up of thirty-six (36) states and a federal capital territory (FCT), which are grouped into six geopolitical regions; North Central, North East, North West, South East, South South and South West. There are 774 constitutionally recognized Local Government Areas 
(LGAs) in the country. The country is in the West African sub region and borders Niger Republic in the North, Chad in the North East, Cameroun in East and Benin Republic in the West. To the South, Nigeria is bordered by a large span of Atlantic Ocean. With a total land area of 923,768 square kilometers, Nigeria exhibits a great variety of relief features encompassing uplands of 600 to 1,300 meters with lowlands of less than 20 meters in the coastal areas. The lowlands extend from the Sokoto plain to the Borno plain. The highland includes the Jos Plateau and the Adamawa highlands in the North, extending to the Obudu Plateau and Oban hills in the South East. Nigeria has a tropical climate with wet and dry seasons associated with the movement of the interTropical Convergence Zone (ITCZ) north and south of the equator. Figure 1 below shows the administrative map of Nigeria.

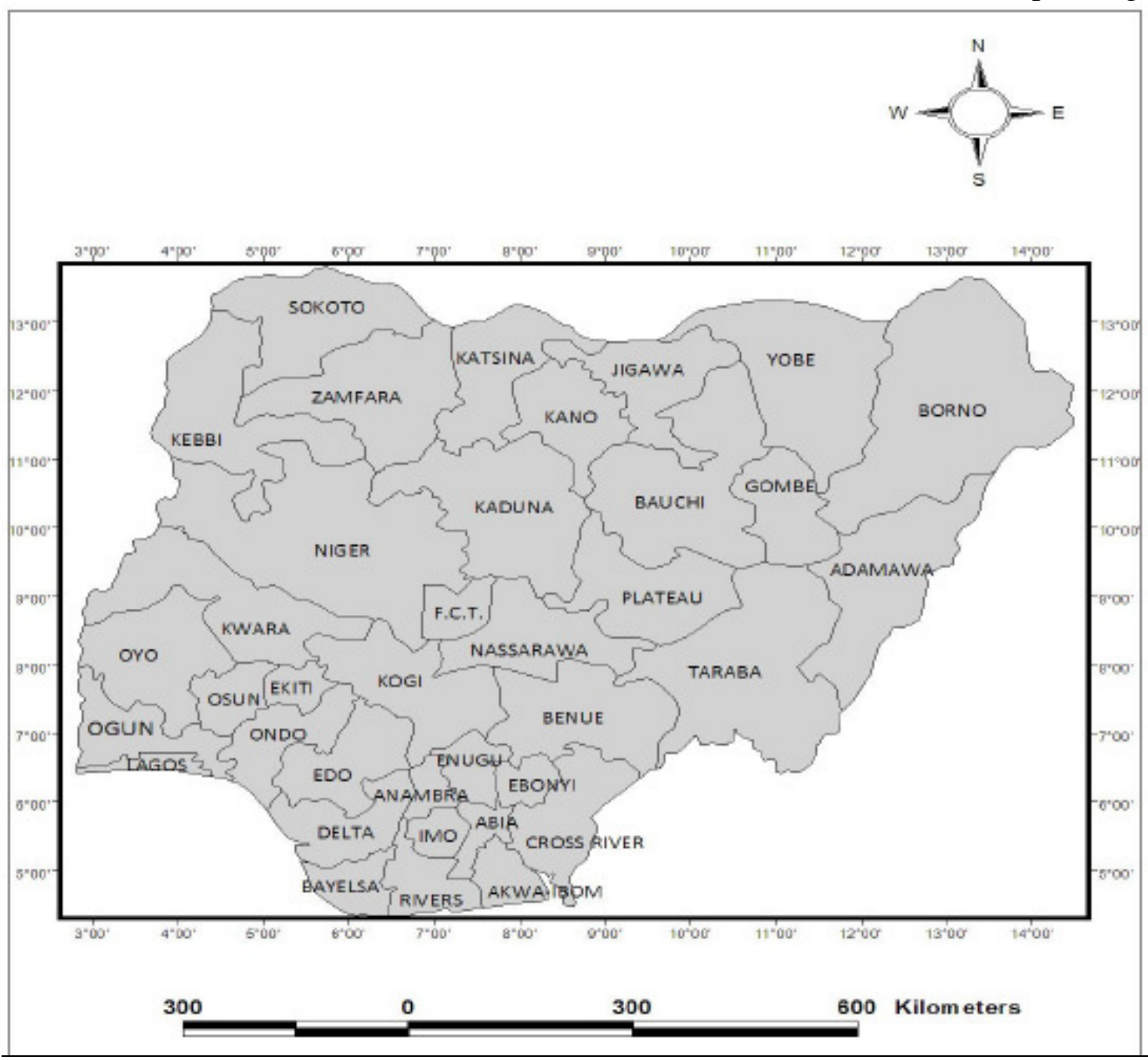

Figure.1: Administrative map of Nigeria

Source: Federal Ministry of Lands and Survey, Ibadan, Oyo state, 2014

\section{Materials and Methods}

The data used for this study was sourced mainly from the dashboard of
Federal Road Safety Corps Planning Advisory Units (2013), National Population Commission (NPC) and Nigerian Tribune 
published Tuesday $3^{\text {rd }}$ April, 2012. The map of Nigeria used was acquired from Federal Ministry of Lands and Survey, Ibadan, Oyo State. The map was scanned and processed using Corel draw 12 into GIS environment. Georeferencing of the map was done using the tie-points method. Digitization was carried out to create spatial data from the existing hard copy of the map of Nigeria using the application of Arc GIS 9.3 by the process of on-screen digitization. States boundaries of the study area were digitized as polygon features, state capitals as point features and road network as line features. Similarly, Microsoft excel was used to build the report from the federal road safety corps dashboard and was exported into the GIS environment via the spatial analyst tool of Arc GIS 9.3.
Results and Discussions

The Trend of Road Traffic Accident rate in Nigeria from 1960-2012

Figure $2 \mathrm{a}$ below shows the trend of road traffic accident in Nigeria between 1960 and 2012 and it was discovered to be increasing steadily fluctuating with highest number of casualties recorded between the year 1976 and 1993 before and after the establishment of Federal Road Safety Commission (FRSC). Highest number of casualties was also recorded in the year 2008 and 2009 while the least number of casualties was recorded in the year 1963. Figure $2.0 \mathrm{~b}$ further revealed that Abuja, Kogi, Nassarawa and Ogun states are having the highest nominal crash values and Abuja been ranked the first.

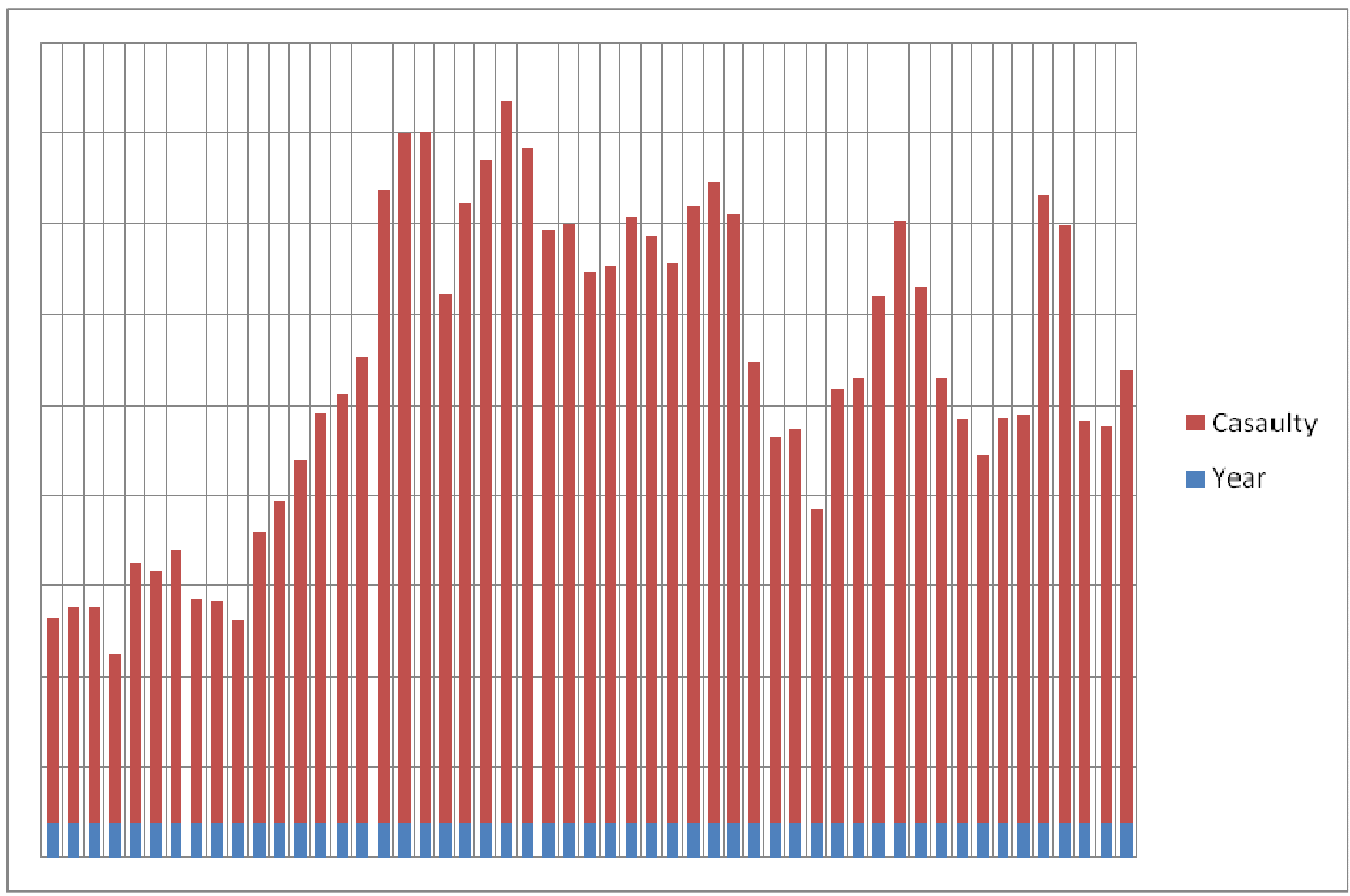

Figure 2: Bar Chart showing the trend of road traffic crashes in Nigeria between 1960 and 2012.

Source: The Dashboard of Federal Road Safety Corps Planning Advisory Units, 2013 


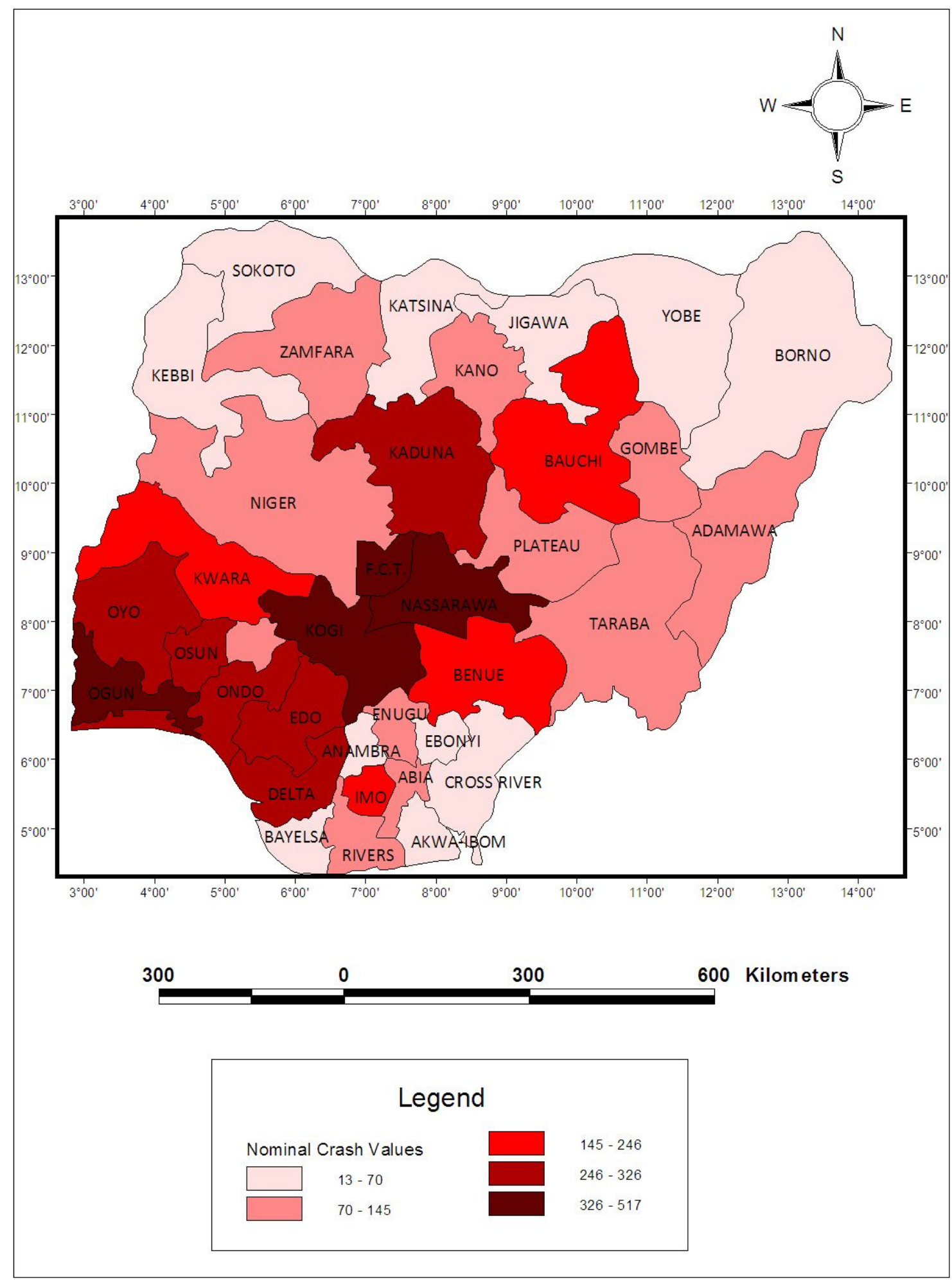

Figure 2b: Map of Nigeria showing the Nominal Crash Values.

Source: Federal Ministry of Lands and Survey, Ibadan,Oyo State, 2014 
State by state (including FCT, Abuja) Road Traffic Crash Fatalities per 100,000 Human Population Using GIS Techniques

It was observed in figure 3 that there was a significant differences in the pattern of state by state including FCT, Abuja road traffic crash fatalities per 100,000 human populations with Abuja (FCT) having the highest rate of fatalities of $6.71 \%$ in year 2012, followed by Lagos, Ogun, Ondo, Edo, Delta, Kogi and Nassarawa states with a fatality rate that ranges between $4.3 \%$ and $6.3 \%$. The figure further shows that Oyo, Kwara, Osun, Kaduna, Bauchi and Gombe states recorded a fatality that ranges between $2.4 \%$ and $4.3 \%$. Niger, Zamfara, Ekiti, Benue, Enugu and Imo states recorded fatalities that ranges from $1.4 \%-2.4 \%$. States like Kebbi, Sokoto, Yobe, Katsina, Jigawa, Borno, Adamawa, plateau, Taraba, Ebonyi, Lagos Rivers, Akwa-Ibom, Cross River, Bayelsa, and Abia had the lowest fatalities rate ranging from $0.5 \%$ to $1.4 \%$.

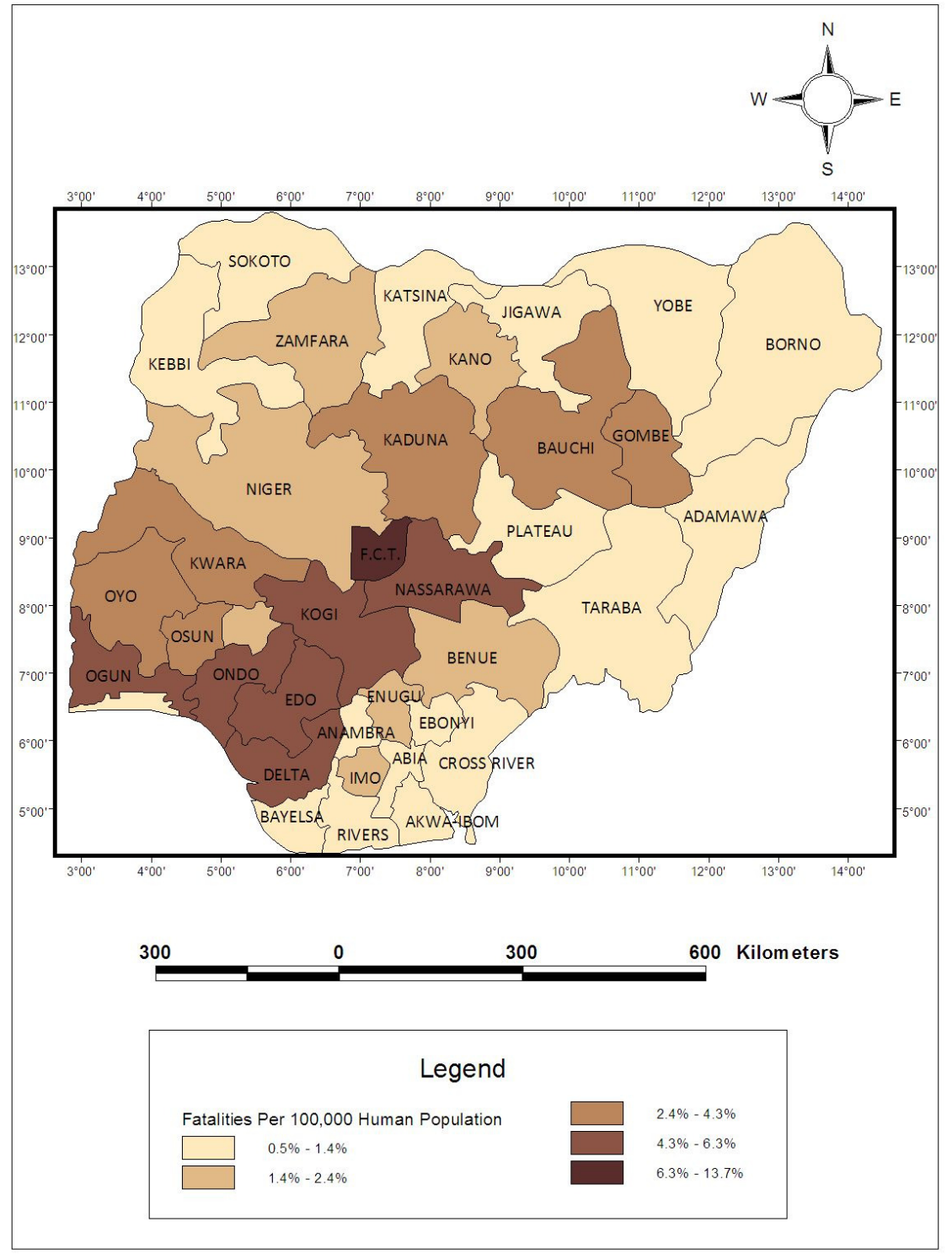

Figure 3: Map of Nigeria showing fatalities per 100,000 human population Source: Federal Ministry of Lands and Survey, Ibadan, Oyo State, 2014. 
Category of vehicles involved in Road Traffic Crashes in 2012 on State basis

Figures 4, 5, 6, 7 and 8 below show that category of vehicles involved in road traffic crashes in year 2012 on states basis varies with Abuja having the highest in terms of cars (470) and buses (198) while Kebbi state is among the states that recorded the least with cars (11) and buses (1). Edo state recorded the highest in terms of number of trucks (122) involved while Kebbi state had no truck involved. For numbers of tanker/trailer that involved in road traffic crash, Edo state recorded the highest (62) followed by Ogun state (58) while Borno, Akwa-Ibom, Abia, Ebonyi, Kebbi, Taraba states are among the states with least record. Nassarawa state (159) has the highest record for number of motorcycles involved followed by Benue (111) and Lagos (110) while the following states recorded the least; Jigawa (2), Kebbi (4), Yobe (5) and Borno (7).

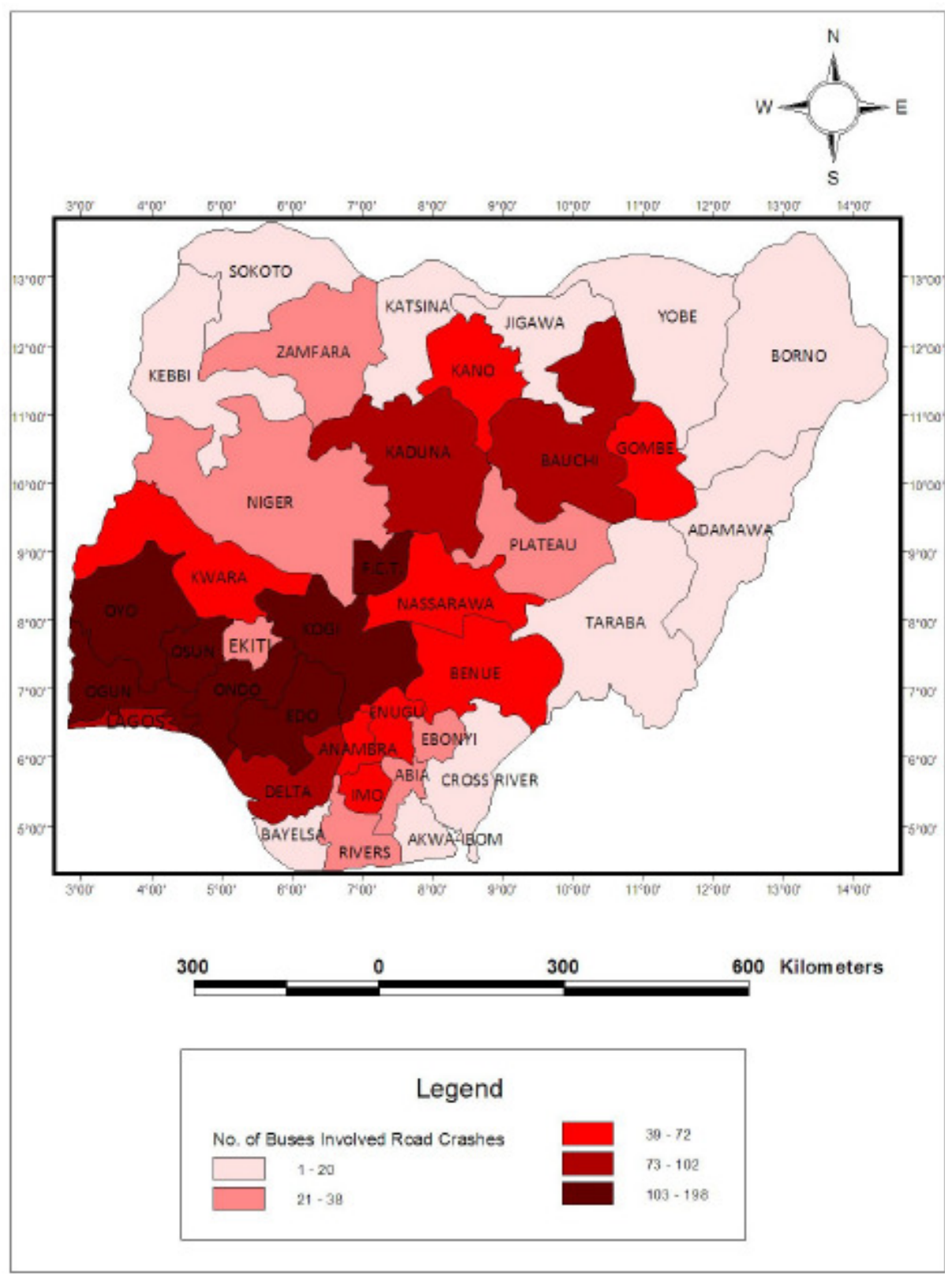

Figure 4: Map of Nigeria showing the number of Buses involved in road crashes Source: Federal Ministry of Lands and Survey, Ibadan, Oyo state, 2014 


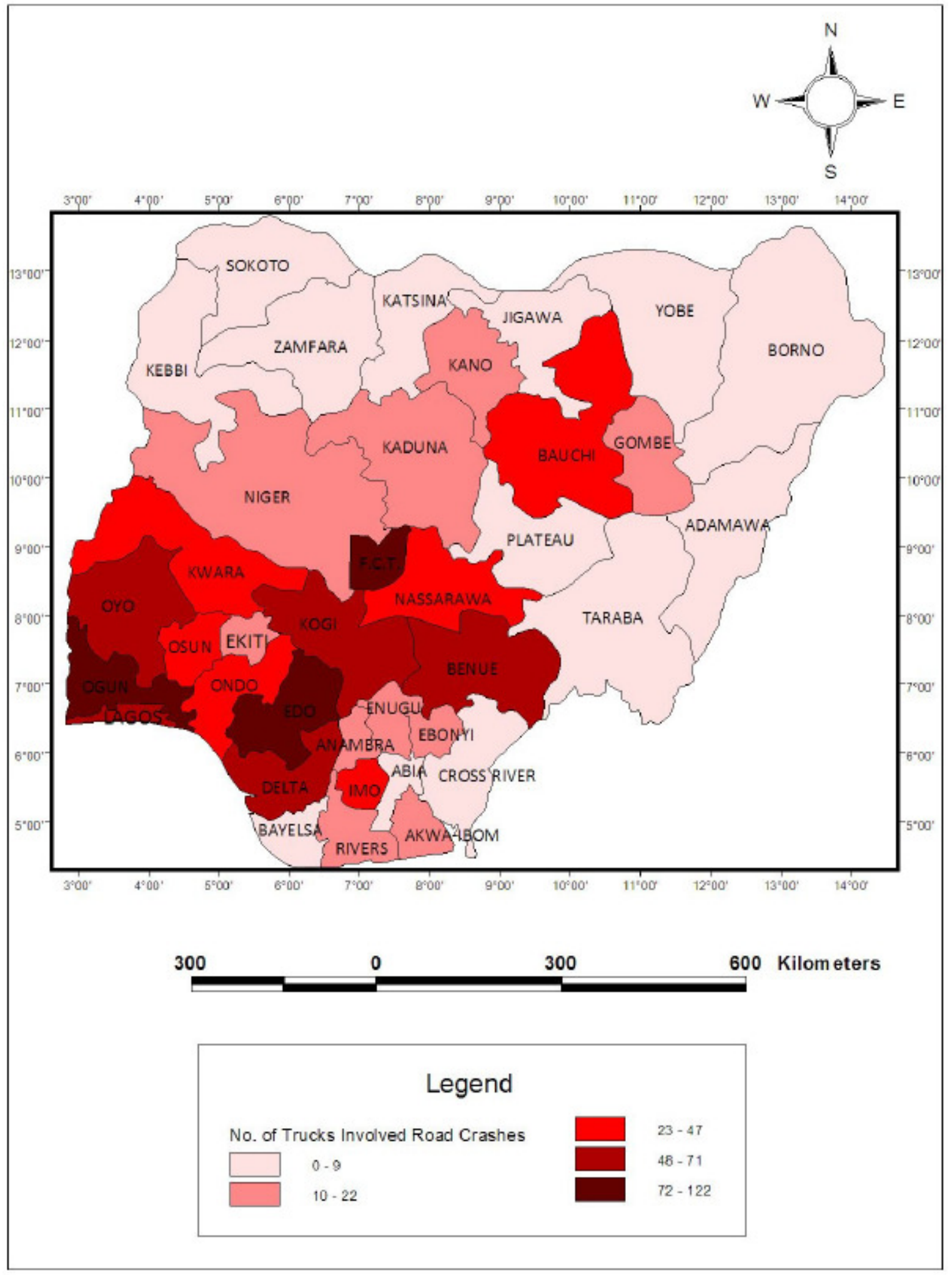

Figure 5: Map of Nigeria showing number of trucks involved in road crashes Source: Federal Ministry of Lands and Survey, Ibadan, Oyo state, 2014 


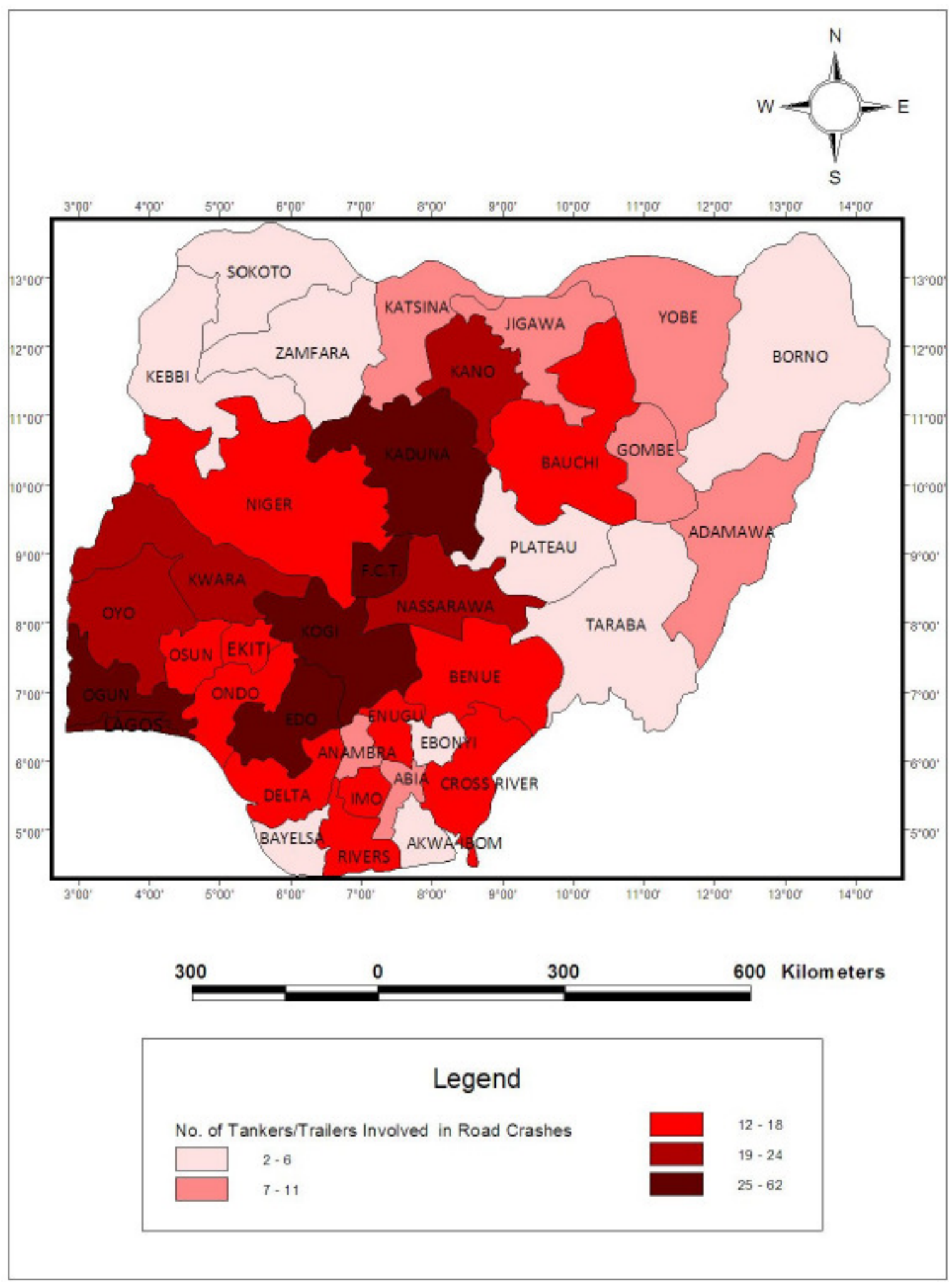

Figure 6: Map of Nigeria showing the number of tankers involved in road crashes Source: Federal Ministry of Lands and Survey, Ibadan, Oyo state, 2014 


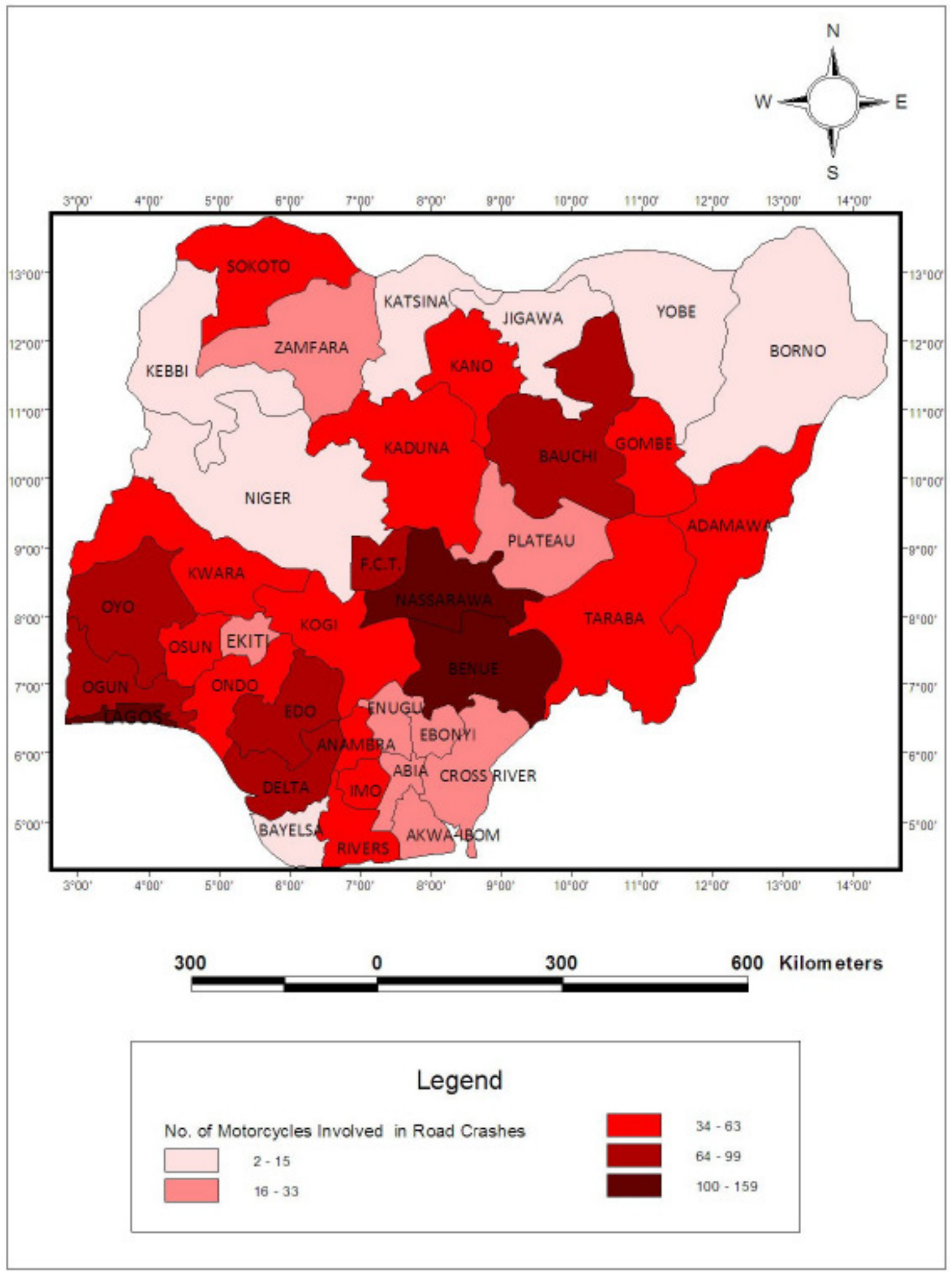

Figure 7: Map of Nigeria showing the number of motorcycles involved in road crashes Source: Federal Ministry of Lands and Survey, Ibadan, Oyo state, 2014 


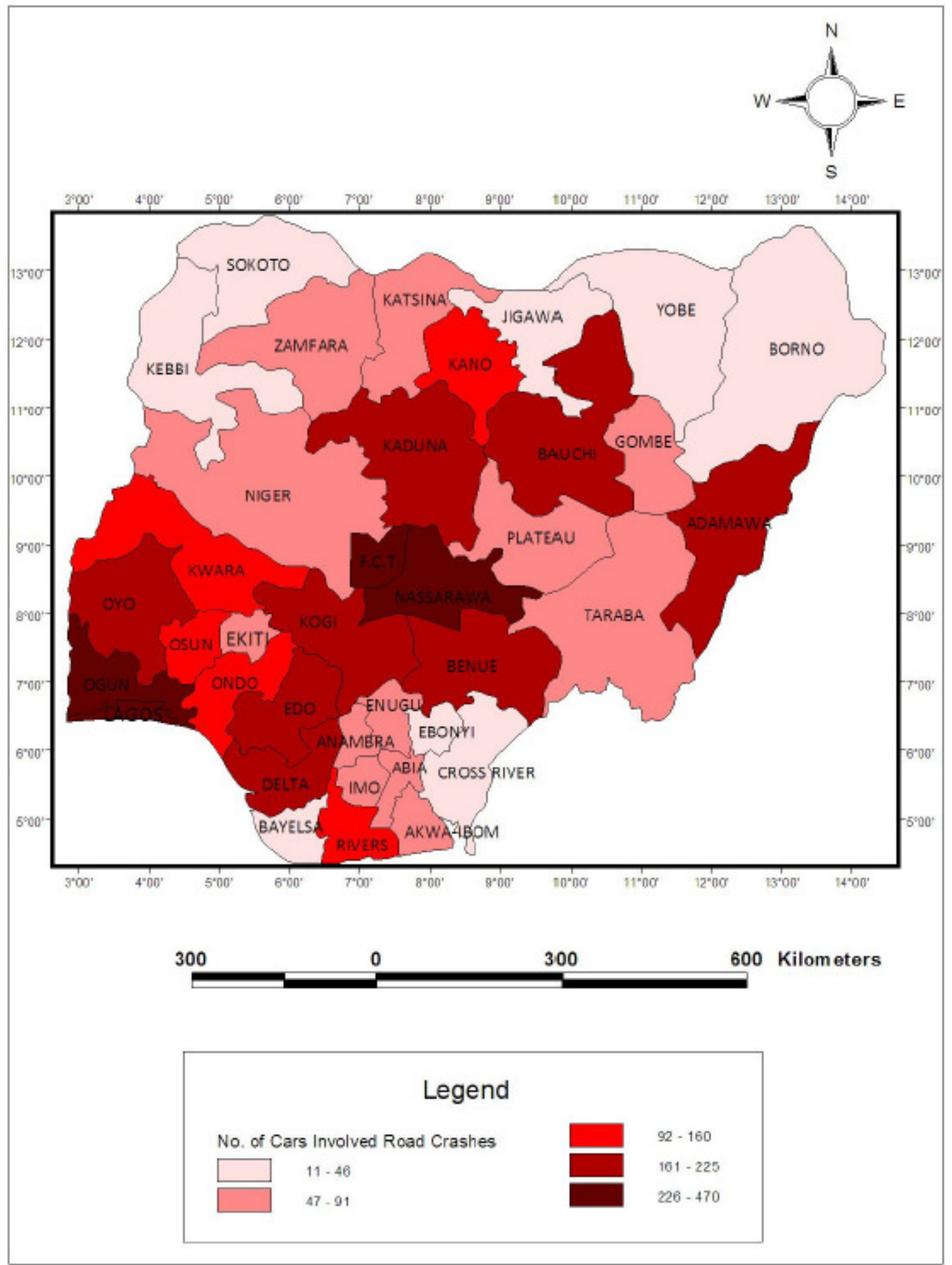

Figure 8: map of Nigeria showing the number of cars involved in road crashes.

Source: Federal Ministry of Lands and Survey, Ibadan, Oyo state, 2014

The levels of cases and degrees of casualties involved in 2012 on State basis

Figures 9,10,11,12 and 13 below show the variation of levels of cases and degrees of casualties with Abuja (FCT) having the highest number of fatal cases (139) followed by Ogun state (130), Edo (118), Oyo (114), Kaduna (108) and Ondo (107) 
while Bayelsa was the least with only seven (7) fatal cases. In terms of serious cases, Abuja had the highest with 278 cases followed by Kogi state with 213 cases while Kebbi state had the least with only one (1) case. Lagos recorded the highest number of minor cases followed by Abuja with 114 cases. Jigawa state has the lowest record with a case. Ogun state recorded the highest number of persons killed (247) while Bayelsa state had only ten (10) persons killed. Number of persons injured also varies from one state to the other with Ogun state recording the highest $(1,395)$ followed by Kogi state $(1,381)$ while Sokoto state had a few number of persons injured (41).

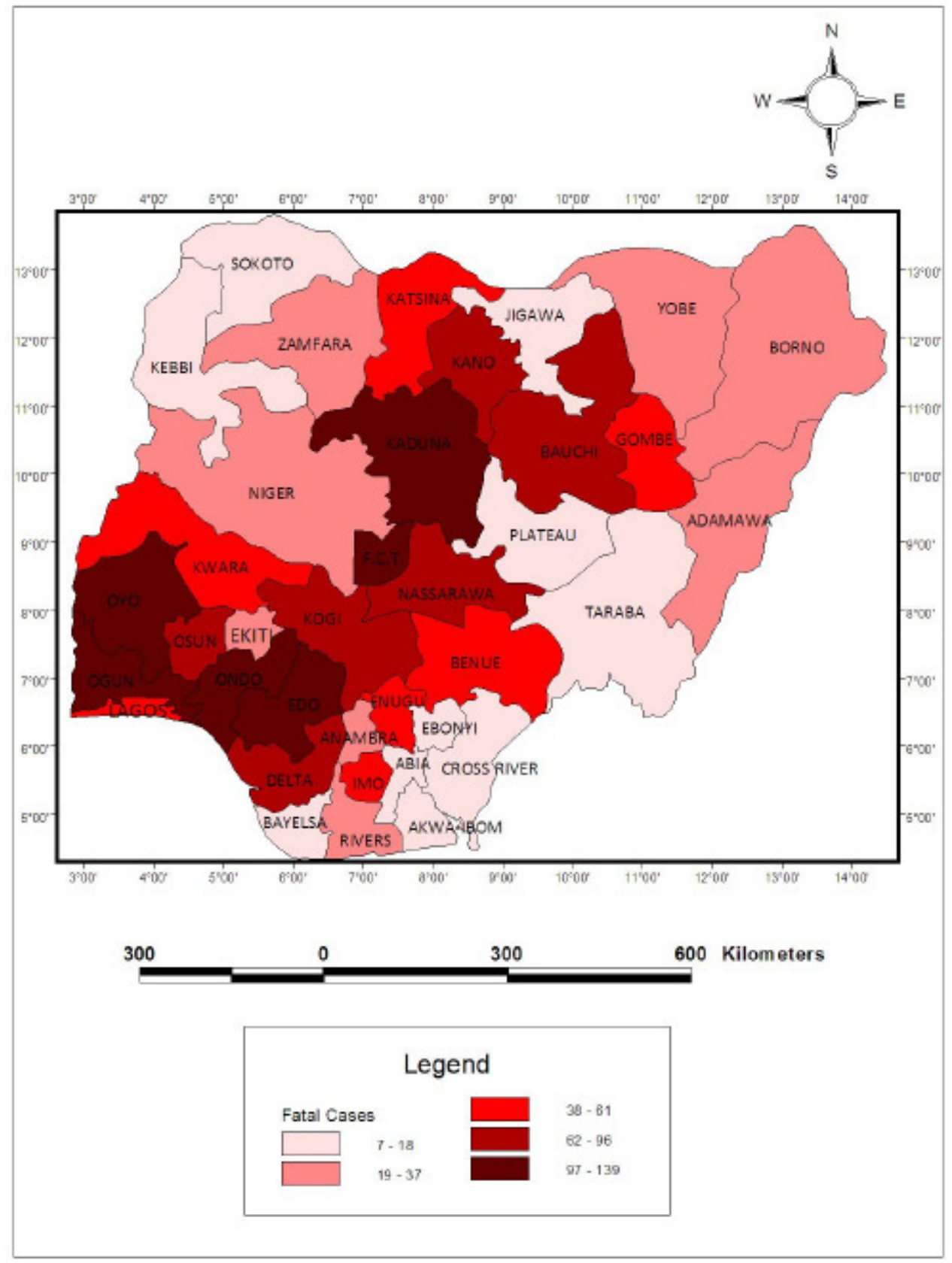

Figure 9: Map of Nigeria showing the pattern of fatal cases of road crashes. Source: Federal Ministry of Lands and Survey, Ibadan, Oyo state, 2014 


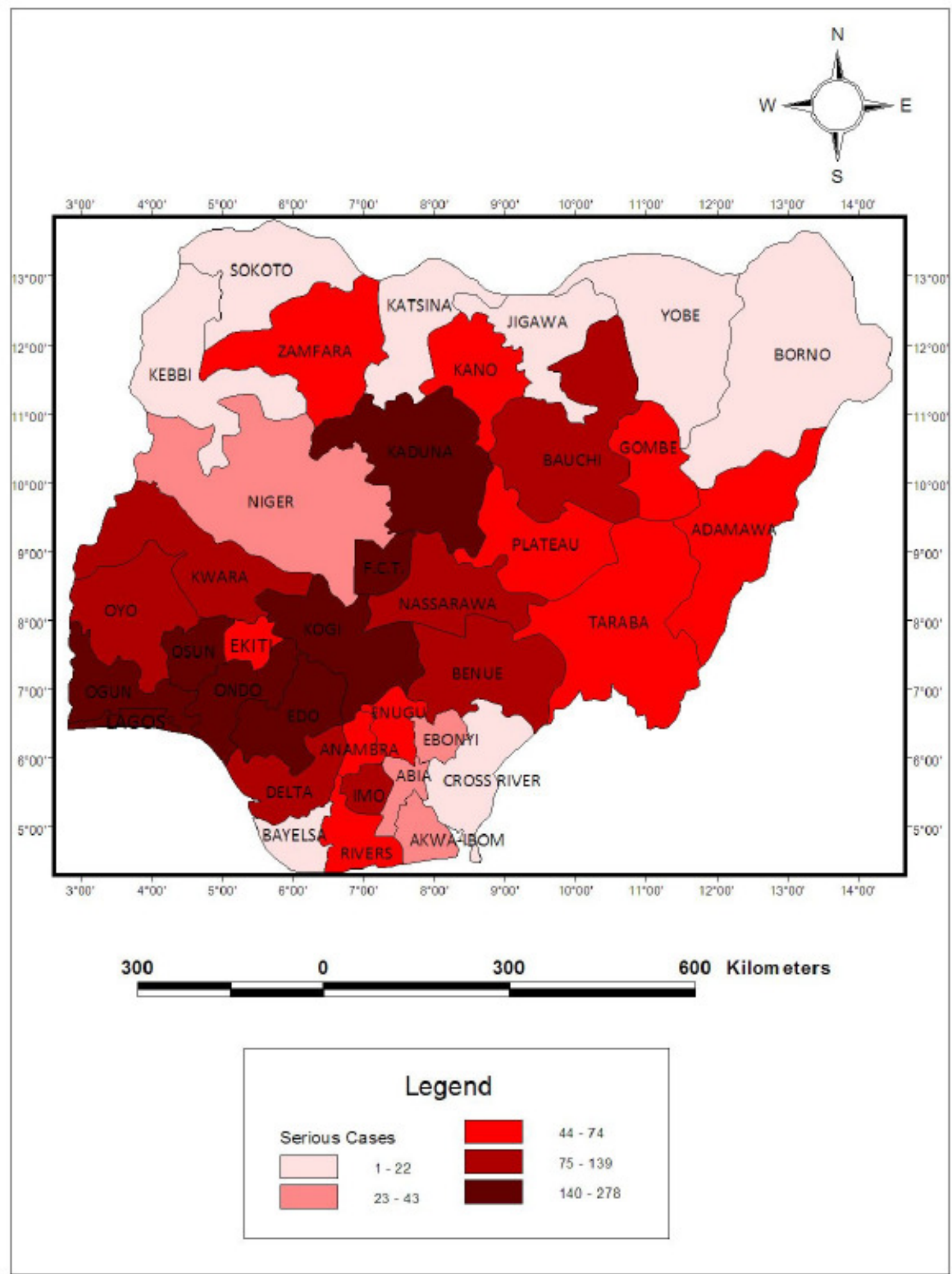

Figure 10: Map of Nigeria showing the pattern of serious cases of road crashes Source: Federal Ministry of Lands and Survey, Ibadan, Oyo state, 2014 


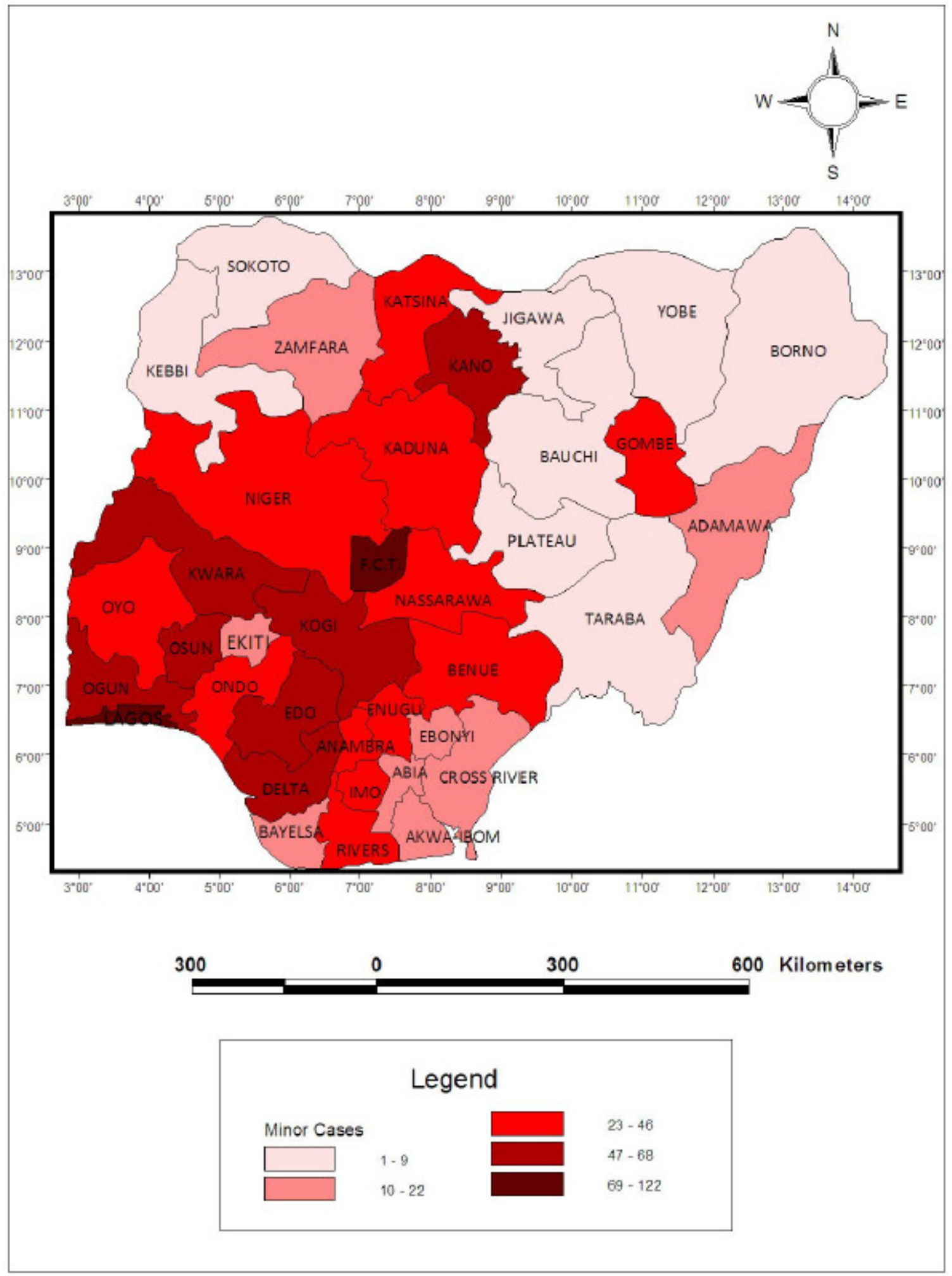

Figure 11: Map of Nigeria showing the pattern of minor cases of road crashes. Source: Federal Ministry of Lands and Survey, Ibadan, Oyo state, 2014 
Ethiopian Journal of Environmental Studies and Management Vol. 8 no. 6, 2015

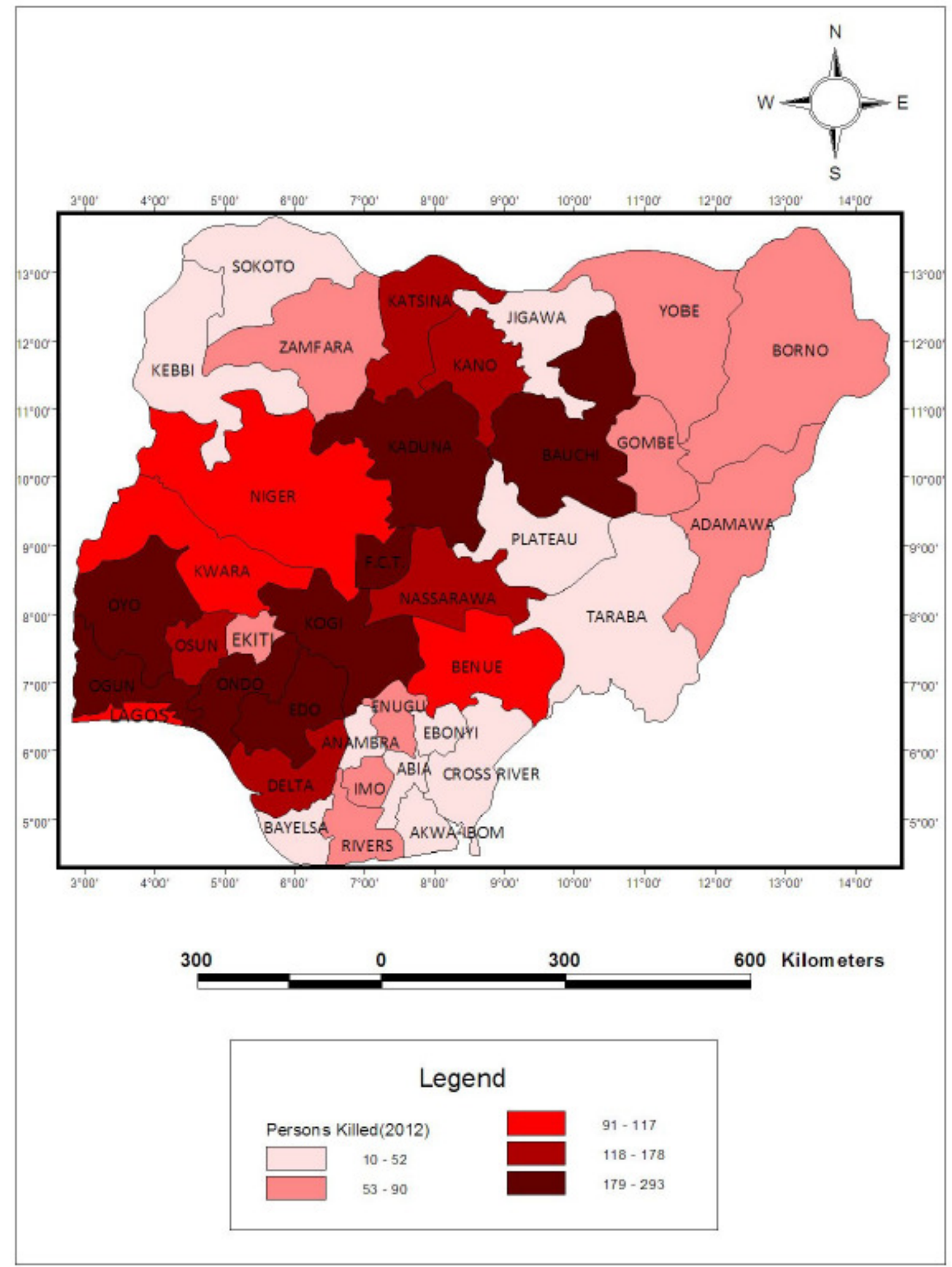

Figure 12:Map of Nigeria showing the pattern of persons killed in road crashes (2012) Source: Federal Ministry of Lands and Survey, Ibadan, Oyo state, 2014 


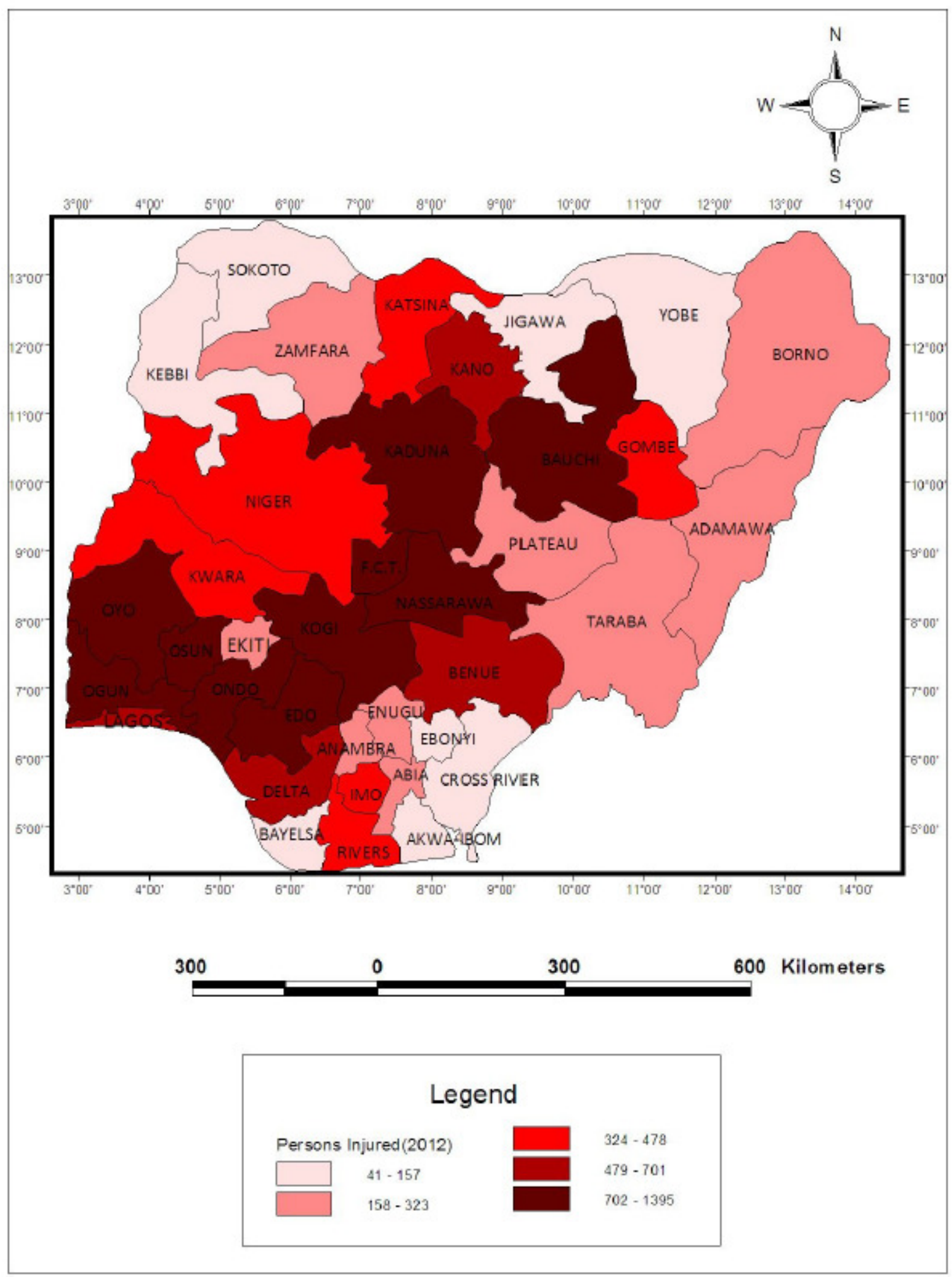

Figure 13: Map of Nigeria showing the pattern of persons injured in road crashes (2012) Source: Federal Ministry of Lands and Survey, Ibadan, Oyo state, 2014 


\section{Conclusions}

This research paper gives an insight of the most road traffic accidents in Nigeria. It can also facilitate spatial data sharing within transportation agencies and between transportation department and other government agencies. This paper equally showed that GIS Technology is able to handle traffic accident analysis. Case study was carried out on Nigeria, an example of developing countries. As the results are given graphically and in map format, it is easy to interpret results.

\section{References}

Adamu, S.O. and Iyaniwura. J.O. (1997). A Road Traffic Accident Model in Onakomaiya. S.O. and Ekanem, N.F. (Eds) Transportation in Nigeria National Development, NISER, Ibadan. Pp 68-75.

Adekunle, J.A. (2010). Road Traffic Accident, death and Soci-Economic Development in Nigeria. Int. Rev.Bus Soc.Sci. 1(5)47-60.
Amos, P. (2005). Reform,
Commercialization and Private Sector

Participation in Railway in Eastern Europe and Central Asia. Transport Papers T4, the World Bank, January 2005. Environmental System Research Institute 'Getting to know ArcGIS Desktop'. 2006.

Augustus, O.A. (2012). Variation in Road Traffic Accident in Lagos state, Nigeria: A Synopsis of Variance Spectra Confluence. Journal of Environmental Studies, 7: 22-33.

Jegede, F.J. (1988). Spatio-Temporal Analysis of Road Accidents in Oyo State. Accident Analysis and Prevention, 18(3): 22-27.

Savena, A. (2011). Environmental and Road Traffic Safety, CRRI, GIS, as an aid to identify accident patterns [Online] Available: http//www.gisdevelopment.net

World Health Organization (2002). A 5year WHO Strategy for road traffic injury prevention retrieved from: http

World Health Organization (2004). World Report on Road Traffic Injury Prevention Summary, Geneva. 